\title{
Comparative study on carcass characteristics between Black Bengal and crossbred goats
}

\author{
M. Asaduzzaman, M. R. Alam ${ }^{1}$, M. R. Amin ${ }^{1}$ and M. O. Faruque \\ Department of Animal Breeding and Genetics, Bangladesh Agricultural University, Mymensingh-2202, Bangladesh \\ ${ }^{1}$ Department of Animal Science, Bangladesh Agricultural University, Mymensingh-2202, Bangladesh
}

\begin{abstract}
This study was conducted on Black Bengal and crossbred goats thrives in the western part of Bangladesh for comparative evaluation of their carcass yield and meat quality. Thirty male goats (15 Black Bengal and 15 crossbreds) slaughtered in the slaughter house of Rajshahi city corporation were evaluated for carcass quantity and quality. The average slaughtering age was 12.60 and 12.40 months, and dressing percentage $43.71 \%$ and $45.86 \%$ for Black Bengal and crossbred goats, respectively. Crossbred goats had significantly $(\mathrm{P}<0.01 \%)$ higher dressing percentage than the Black Bengal goats. The total edible and non edible portions of Black Bengal and crossbred goats did not differ significantly $(p>0.05)$. The percentage of moisture, crude protein, ether extract and ash contents were 72.79, 21.90, 3.72 and 1.15 for Black Bengal goat and 73.46, 20.85, 4.51 and 1.08 for crossbred goats, respectively. There was no significant difference ( $p>0.05)$ among moisture, crude protein, ash content (\%) of Black Bengal and Crossbred goats. However, the carcass of crossbred goats contained more fat (ether extract) $(p<0.05)$ compared to the Black Bengal goat. The higher carcass yield and dressing percentage observed in crossbred goats reflected to yield more meat compared to the Black Bengal goat.
\end{abstract}

Keywords: Black Bengal and Crossbred goat, Dressing percentage, Chemical composition

\section{Introduction}

Meat is one of the most nutritious food in human diet. Chevon (Goat meat) is most popular meat of ruminant species and is accepted by all communities in Bangladesh. According to FAO (2006), the country possesses 35 million goat and produced 1,82,000 Ton of chevon in 2005. Chevon is obtained from goat of different genotypes like Black Bengal, exotic breeds (mainly Sirohi and Beetal) and crossbred goats (cross between Black Bengal and exotic breeds) in Bangladesh. Black Bengal is a dwarf animal produces about $6.0 \mathrm{~kg}$ carcass (Devendra and Owen, 1983; Das, et al., 2002; Moniruzaaman at al. 2002; Abedin et al. 2005). Black Bengal is a predominant goat in the country and is famous for its prolificacy, meat and skin quality. Bucks of exotic breeds are being imported privately from India and used for crossbreeding, especially in the western part of the country. The real number of crossbred goat population is not known; but mostly found in Rajshahi, Pabna, Kustia, Chuadanga, Jinaidah and Jessore district (Faruque and Khandoker, 2007). The crossbred goat is becoming more and more popular to the western part of the country due to their larger body size, more carcass yield and more market price as compared to Black Bengal goat. There is no scientific work on the comparative meat yield and quality of Black Bengal and crossbred goat in the country, except a report of Amin et al. (2000) on the comparative study of carcass quantity and quality for Black Bengal and crossbred (Jamnapari X Black Bengal) goat in Mymensingh district. The present study was therefore conducted to find the carcass quantity and quality of Black Bengal and crossbred (Black Bengal $X$ Sirohi) goat in the western part of the country.

\section{Materials and Methods}

The data were obtained from Black Bengal and crossbred goats from 30 male goats (15 Black Bengal and 15 crossbred goats) of approximately one year of age slaughtered at the slaughter house of Rajshahi city corporation during the month of June to September, 2008. The age of the animals was estimated by visual observation, interviewing the owners and by dentition. The weight of the goat, carcass and different body portions was taken with the help of weighing balance. Representative meat samples from 10 male goats (5 Black Bengal and 5 crossbred goats) were collected for chemical analysis. 
Data on empty stomach body weight at slaughter, warm carcass weight and weight of visceral organs (heart, liver, lung, pluck, kidney, spleen) head, gut, legs and skin were weighed and recorded. Blood were collected in the polythyne packet and weighed with the help of weighing balance.

Meat samples from different parts of carcass of Black Bengal and crossbred goats were ground separately and representative samples for each breed analyzed for moisture, crude protein (CP), ether extract (EE) and ash on fresh basis following the method of AOAC (1975) in Animal Science Laboratory of Bangladesh Agricultural University, Mymensingh.

All the experimental data were analyzed for their differences by paired t- test using statistical package for social science 11.5 (SPSS 11.5) (SPSS Inc. 1999, Microsoft Corporation, 1998) windows package.

\section{Results and Discussion}

\section{Carcass weight and dressing Percentage}

The average age and weight at slaughtering, carcass weight and dressing percentage of Black Bengal and crossbred goats have been presented in Table 1 . The live weight, carcass weight and dressing percentage of crossbred goats were significantly $(P<0.01 \%)$ higher than those of Black Bengal goats at the same age. The dressing percentage observed in this study is similar to the value of $41.48 \%$ to $43.73 \%$ reported by Abedin et al. (2005), Moniruzzaman et al. (2002) and Das et al. (2001). However, a lower dressing percent of Black Bengal goats (38.61) was also been reported by Singh et al. (1985) in Indian Black Bengal goat. Chowdhury and Faruque (2004) reported dressing percent of Black Bengal goat between 181 and 365 days of age was 46.4\%. Amin et al. (2000) reported $42.44 \%$ for crossbred goat (Black Bengal X Jamnapari), Devendra and Owen (1983) and Verma et al. (2004) reported the value of $48.10-52.15 \%$ for Indian pure breed goats. The higher carcass weight and dressing percentage of crossbred goats over Black Bengal goats might be due to heterosis effect. The variation in dressing percentage of Black Bengal goats observed by different investigators might be due to variation in age, body condition and nutritional status of the slaughtered animals.

Table 1. Carcass yield of Black Bengal and Crossbred goats

\begin{tabular}{|c|c|c|c|}
\hline Parameters & $\begin{array}{l}\text { Black Bengal goat }(n=15) \\
\quad(\text { Mean } \pm \text { SE) }\end{array}$ & $\begin{array}{l}\text { Crossbred goat }(n=15) \\
\quad(\text { Mean } \pm \text { SE) }\end{array}$ & $\begin{array}{l}\text { Level of } \\
\text { significance }\end{array}$ \\
\hline Age at slaughter (month) & $12.60 \pm 0.89$ & $12.40 \pm 1.52$ & NS \\
\hline Empty live wt (kg) & $13.56 \pm 1.13$ & $19.74 \pm 1.72$ & ** \\
\hline Warm carcass weight $(\mathrm{kg})$ & $5.93 \pm 0.46$ & $9.06 \pm 0.83$ & ** \\
\hline Dressing percentage & $43.71 \pm 0.56$ & $45.87 \pm 0.40$ & ** \\
\hline
\end{tabular}

** = Significant at $\mathrm{P}<0.01, \mathrm{NS}=$ Non significant

\section{Total edible portions}

Dressed carcass and edible portions were collectively considered as total edible portion. The total edible portions of Black Bengal and crossbred goats are presented in Table 2. There was no significant difference $(P>0.05)$ between the total edible portions of Black Bengal and crossbreed goats. However, head, liver, spleen, kidney and leg of crossbred goats were significantly higher $(p<0.05)$ than those of Black Bengal goat. This might be due to heterosis effect. Abedin et al. (2005) reported lower value of total edible portions meat of Black Bengal goat $(57.87 \%)$ than that of the present study (64.29\%). The higher edible portion of goat meat in the present study is due to inclusion of feet in the edible portion. Abedin et al. (2005) included feet $(4.09 \%$ of the total weight) in the non edible portion. However, if the feet are included in the edible portion, then the finding of the present study is similar to that of Abedin et al. (2005). In other study, Devendra and Owen (1983) reported higher edible portion (62.20\% to $71.50 \%$ ) in Far East goat. 
Table 2. Total edible portions of Black Bengal and crossbred goats

\begin{tabular}{|c|c|c|c|}
\hline Parameters & $\begin{array}{c}\text { Black Bengal } \\
\text { goat }(n=15)(\text { Mean } \pm \text { SE) }\end{array}$ & $\begin{array}{l}\text { Crossbred goat }(n=15) \\
\quad(\text { Mean } \pm \text { SE) }\end{array}$ & $\begin{array}{l}\text { Level of } \\
\text { significance }\end{array}$ \\
\hline Empty live wt (kg) & $13.56 \pm 1.13$ & $19.74 \pm 1.72$ & ** \\
\hline Warm carcass weight $(\mathrm{kg})$ & $5.93 \pm 0.46$ & $9.06 \pm 0.83$ & ** \\
\hline Head $(\mathrm{kg})$ & $0.95 \pm 0.05$ & $1.10 \pm 0.10$ & * \\
\hline Heart (g) & $70.40 \pm 7.47$ & $75.40 \pm 5.32$ & NS \\
\hline Liver (g) & $387.60 \pm 38.97$ & $483.40 \pm 82.48$ & * \\
\hline Lung + trachea $(\mathrm{g})$ & $177.40 \pm 21.65$ & $181.80 \pm 5.59$ & NS \\
\hline Pluck (g) & $635.40 \pm 62.28$ & $741.20 \pm 84.68$ & * \\
\hline Spleen $(\mathrm{g})$ & $48.80 \pm 5.72$ & $59.20 \pm 3.70$ & * \\
\hline Kidney (two, g) & $58.20 \pm 9.44$ & $75.20 \pm 6.94$ & * \\
\hline Feet (four, g) & $460.60 \pm 76.07$ & $644.60 \pm 112.01$ & * \\
\hline Total edible portion (\%) & $64.29 \pm 0.71$ & $62.07 \pm 0.73$ & NS \\
\hline
\end{tabular}

* = Significant at $\mathrm{P}<0.05 ; * \star=$ Significant at $\mathrm{P}<0.01, \mathrm{NS}=$ Non significant

\section{Total non-edible portions}

Skin, gut and blood were considered as total non-edible portions. The total non-edible portions of Black Bengal and crossbred goats are presented in Table 3 . There was no significant variation ( $p>0.05$ ) between the total non-edible portions of Black Bengal and crossbred goats. Gut weight and blood weight of crossbred goat were significantly higher $(p<0.01)$ than those of Black Bengal goat. But skin weight of both types of goats did not differ significantly ( $p>0.05$ ). Abedin et al. (2005) observed $34.13 \%$ of Black Bengal goat carcass was total non-edible portions of meat which was slightly lower than that of the present study. This might be reflected due to higher skin and gut weight of Black Bengal goat of the present study than those of Abdin et al. (2005). Moniruzzaman et al. (2002) found the blood weight of Black Bengal goats was $541.66 \mathrm{~g}$ which was slightly lower than that of the present study (558.00\%).

Table 3. Total non-edible portions of Black Bengal and Crossbred goats

\begin{tabular}{|l|c|c|c|}
\hline Parameters & $\begin{array}{c}\text { Black Bengal goat } \\
(\mathrm{n}=15)(\text { Mean } \pm \text { SE) }\end{array}$ & $\begin{array}{c}\text { Crossbred goat }(\mathrm{n}=15) \\
(\text { Mean } \pm \mathrm{SE})\end{array}$ & $\begin{array}{c}\text { Level of } \\
\text { significance }\end{array}$ \\
\hline Empty live wt $(\mathrm{kg})$ & $13.56 \pm 1.13$ & $19.74 \pm 1.72$ & $\star *$ \\
\hline Skin $(\mathrm{kg})$ & $0.95 \pm 0.07$ & $1.01 \pm 0.05$ & $\mathrm{NS}$ \\
\hline Gut $(\mathrm{kg})$ & $3.37 \pm 0.24$ & $5.43 \pm 0.44$ & $\star *$ \\
\hline Blood $(\mathrm{g})$ & $558.00 \pm 81.06$ & $720.00 \pm 75.83$ & $\star \star$ \\
\hline Total non-edible portion $(\%)$ & $35.96 \pm 0.64$ & $36.31 \pm 1.04$ & $\mathrm{NS}$ \\
\hline
\end{tabular}

** = Significant at $\mathrm{P}<0.01, \mathrm{NS}=$ Non significant

\section{Chemical composition of carcass}

Carcass chemical composition of Black Bengal and crossbred goats is shown in Table 4. Moisture, crude protein and ash content did not differ significantly $(p>0.05)$ between Black Bengal and crossbred goats. But the fat content of crossbred goats was significantly higher $(P>0.01)$ than that of Black Bengal goat. This might be due to the genotypic effect or feeding of more concentrate feeds to crossbred goats as compared to Black Bengal goat. Protein contents of Black Bengal goat in the present study agreed with the findings reported by Amin at al. (2000), Moniruzzaman et al. (2002) and Abedin et al. (2005). Verma et al. (1996) reported slightly higher protein contents in chevon of Indian breed. Fat contents of Black Bengal goat in the present was little higher than the value reported by Abedin et al. (2005) but was lower than that of the findings of Chowdhury and Faruque (2004). The ash contents of Black Bengal goats of the present study was almost similar reported by Abedin et al. (2005), but it was higher than that reported by Moniruzzaman et al. (2002). 
Table 4. Carcass chemical composition of Black Bengal and crossbred goat

\begin{tabular}{|l|c|c|c|}
\hline Parameters & $\begin{array}{c}\text { Black Bengal goat }(n=5) \\
(\text { Mean } \pm \text { SE) }\end{array}$ & $\begin{array}{c}\text { Crossbred goat }(n=5) \\
\text { (Mean } \pm \text { SE) }\end{array}$ & Level of significance \\
\hline Moisture (\%) & $72.79 \pm 0.73$ & $73.46 \pm 0.73$ & NS \\
\hline CP $(\%)$ & $21.90 \pm 0.63$ & $20.85 \pm 0.49$ & NS \\
\hline EE $(\%)$ & $3.72 \pm 0.40$ & $4.51 \pm 0.63$ & NS \\
\hline Ash (\%) & $1.15 \pm 0.10$ & $1.08 \pm 0.09$ & \\
\hline
\end{tabular}

* $=$ Significant at $\mathrm{P}<0.05, \mathrm{NS}=$ Non significant

\section{Conclusion}

From the results of the present study, it can be concluded that the carcass yield and dressing percentage of crossbred goats were higher than those of Black Bengal goats. This might be due to heterosis effect. Meat quality of crossbred goats in terms of chemical composition (moisture, crude protein and ash content) was almost similar to that of Black Bengal goats with exception to higher percent of ether extract in crossbred goats.

\section{Acknowledgement}

The authors are grateful to International Atomic Energy Agency and Bangladesh Agricultural University for financial support to conduct this study. Thanks also to the butchers of Rajshahi city corporation for their assistance to collect the data for this study and Mr. Delwar Hussain, laboratory technician, for his assistance to conduct the laboratory analysis.

\section{References}

Abedin, S.M.A., Alam, M.R. and Faruque, M.O. 2005. Comparative carcass characteristics of ruminant species in Bangladesh. J. Bangladesh Agric. Univ. 3 (2): 243-249.

Amin, M.R., Husain, S.S. and Islam, A.B.M.M. 2000. Evaluation of Black Bengal goats and their cross with Jamnapari breed for carcass characterisitics. Small Ruminant Research. 38 (3): 211-215.

AOAC. 1975. Official Method of Analysis. (12 ${ }^{\text {th }}$ edn), Association of Official Analytical Chemists. Washington DC, USA.

Chowdhury, S.A. and Faruque, S. 2004. Meat production characteristics of Black Bengal goat. AJAS. 17(6): 848-856.

Das, S., Husain, S.S.,Hoque, M.A. and Amin, M.R. 2001. Association between body measurement and carcass characteristics of goats. Bang. J. Anim. Sci. 30(1-2): 85-91.

Devendra, C. and Owen. J.E. 1983. Quantitative and qualitative aspects of meat production from goats. World Animal Review. 47: 19- 29.

FAO. 2006. Production year book 2006. Food and Agriculture Organization of United Nations, Rome, Italy.

Faruque, M.O. and Khandokar, M.A.M.Y. 2007. Recent advances of goat genotyping in Bangladesh- genotyping for breed and type determination. In Proc. Workshop on Recent advances of livestock genotyping in Bangladesh: Genotyping of goats and buffaloes for breed and type determination. May 10, 2007, Dhaka. pp 28-40.

Moniruzzaman, M., Hashen, M.A., Akther, S. and Hossain, M.M. 2002. Effect on different feeding system on carcass and noncarcass parameters of Black Bengal goats. AJAS. 15(1): 61-65.

SPSS, Windows for version-11.5.Release on 27.10.1999 (Microsoft Corporation, 1998). Trends SPSS Inc., Michigan Avenue, Chicago, IL. 19-82.

Verma, A.K., Sasty, V.R.B. and Agarwal, D.K. 1996.Chevon characteristics of goats fed diets with water washed neem (Azedirachta indica) seed karnel cake. Small Ruminant Research. 19(1): 55-61. 